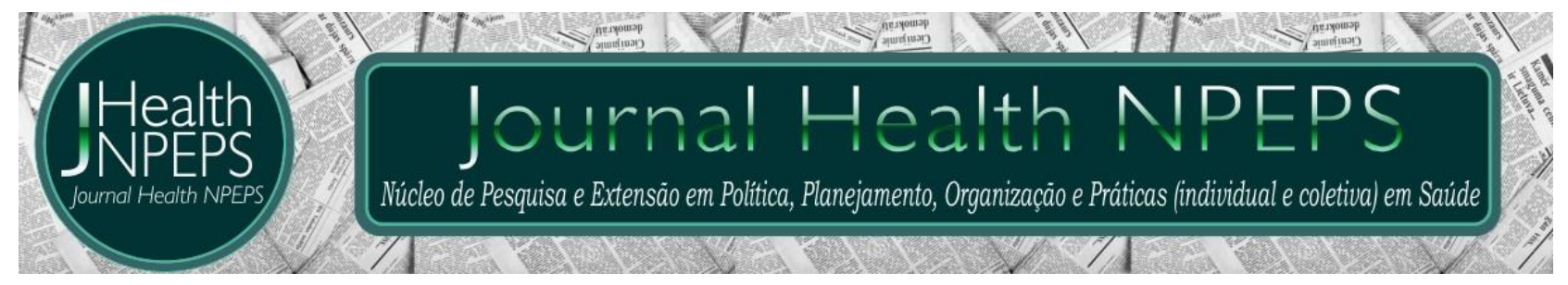

http://dx.doi.org/10.30681/252610103131

ARTIGO ORIGINAL

\title{
Histological analysis of rat prostate under exogenous testosterone and low dose of oral selenium administration
}

\begin{abstract}
Histología de la próstata de ratón influenciada por testosterona y la dosis supranutricional de selenio
\end{abstract}

\section{Histologia da próstata de rato sob influência de testosterona exógena e dose supra- nutricional de selênio}

Sergio Marcelino de Oliveira ${ }^{1}$, Loiane dos Santos Silva ${ }^{2}$, Rafaela Heloise Cardoso Ledesma ${ }^{3}$, Rodolpho Gonçalves da Silva ${ }^{4}$

\begin{abstract}
Objective: to verify selenium effectiveness in maintenance of prostate tissue architecture. Method: experimental study using 20 adult 90 -day-old male rats divided into the following groups: TG, 05 animals that received injectable testosterone; TSG, 05 animals that received injectable testosterone and weekly doses of selenium by gavage; CG1, 05 intact animals; CG2, 05 animals that received saline injection and saline by gavage. Results: characteristic architecture was found in tissue samples from animals of CG with cubic/prismatic secretory epithelium surrounded by fibro-muscular stroma. Animals of TG showed an increase in prostatic epithelium height, increase in the number of blood vessels in stroma and presence of proliferative lesions. Proliferative lesions were also found in tissue samples from animals of TSG, besides having improve in epithelial height, as seen in TG. Conclusion: it is concluded that selenium at this concentration has no effectiveness in modulating morphology of prostatic tissue of adult rats.
\end{abstract}

Descriptors: Prostate; Testosterone; Selenium compounds.

\section{RESUMEN}

Objetivo: verificar la eficacia del selenio en mantener la morfología tisular. Método: estudio experimental, utilizando 20 ratones machos adultos (5 animales/grupo),

\footnotetext{
${ }^{1}$ Biólogo. Doutor. Professor Adjunto da Universidade Federal de Mato Grosso (UFMT), Campus Universitário do Araguaia UFMTCUA. Barra do Garças, Mato Grosso, Brasil. E-mail: sergio-marcelino@ufmt.br ORCID ID: https://orcid.org/0000-0002-6314-0882 Autor principal - Endereço para correspondência: Av. Universitária, 3.500, Secretaria do ICBS, UFMT, Pontal do Araguaia-MT.

Bióloga. Graduada pelo Centro Universitário de Rio Preto (UNIRP). São José do Rio Preto, São Paulo, Brasil. E mail: loiane.santos@gmail.com.br ORCID ID: https://orcid.org/0000-0002-0502-2327

${ }_{3}^{3}$ Médica Veterinária. Graduada pelo Centro Universitário de Rio Preto (UNIRP). São José do Rio Preto, São Paulo, Brasil. E mail: rafaledesma@gmail.com.br ORCID ID: https://orcid.org/0000-0003-0213-4398

${ }^{4}$ Biólogo. Graduado pelo Centro Universitário de Rio Preto (UNIRP). São José do Rio Preto, São Paulo, Brasil. E mail: rodolpho.goncalves@gmail.com.br ORCID ID: https://orcid.org/0000-0002-1242-6725
}

Este artigo está licenciado sob forma de uma licença Creative Commons Atribuição 4.0 Internacional, que permite uso irrestrito, distribuição e reprodução em qualquer meio, desde que a publicação original seja corretamente citada. 
divididos en: TG, recibieron testosterona inyectable; TSG, recibieron testosterona inyectable y dosis semanales de selenio por gavado; CG1, animales intactos; CG2, recibieron solución salina inyectable y por gavado. Resultados: una arquitectura característica fue encontrada en las muestras tisulares de los animales del CG, con epitelio cúbico/prismático envuelto por estroma fibro-muscular. En los animales del TG la próstata presentó un epitelio con células más altas, un aparente aumento en el número de vasos sanguíneos estromais, además de la presencia de lesiones proliferativas. También se encontraron lesiones proliferativas en las muestras tisulares de los animales del TSG, además de presentar mayor altura del epitelio, como vistas en TG. Conclusión: se concluye así que el Selenio, en esta concentración, parece no ser eficaz en la protección contra las modificaciones promovidas por la administración de $T$ exógena en ratas adultas.

Descriptores: Próstata; Testosterona; Compuestos de Selenio.

\section{RESUMO}

Objetivo: verificar a eficácia do selênio na manutenção da morfologia tecidual prostática. Métodos: estudo experimental, utilizando 20 ratos machos adultos, divididos em: TG, 05 animais que receberam testosterona injetável; TSG, 05 animais que receberam testosterona injetável e doses semanais de selênio por gavagem; CG1, 05 animais intactos; CG2, com 05 animais que receberam solução salina injetável e por gavagem. Resultados: uma arquitetura característica foi encontrada nas amostras teciduais dos animais do CG, com epitélio cúbico/prismático envolvido por estroma fibro-muscular. Nos animais do TG a próstata apresentou um epitélio com células mais altas, um aparente aumento no número de vasos sanguíneos no estroma, além da presença de lesões proliferativas. Também foram encontradas lesões proliferativas nas amostras teciduais dos animais do TSG, além de apresentarem maior altura do epitélio, como vistas no TG. Conclusão: conclui-se assim, que o selênio, nesta concentração, parece não ser eficaz na proteção contra as modificações promovidas pela administração de T exógena em ratos adultos.

Descritores: Próstata; Testosterona; Compostos de Selênio.

\section{INTRODUCTION}

Prostate gland is the only gland in male reproductive system found in all mammals ${ }^{1}$. In rodents it is divided into three pairs of distinct lobes being called lateral, ventral and dorsal according to their location in relation to urethra. These lobes are connected to urethra by ducts, which are functionally similar to the human prostate ${ }^{2}$. Benign Prostatic Hyperplasia (BPH), an androgen-dependent disease, affects about 10\% of men in early 30s and is found in $90 \%$ of mans over 90 years old ${ }^{3}$. Regarding prostate cancer, prostate cancer is the most frequent cancer in men and it is diagnosed in $18 \%$ of the males to the end of their lives 3 .

Cancer is an uncontrolled growth of cells that escape the control of regulatory factors that promote formation of an abnormal mass of tissue ${ }^{4}$. Several mechanisms are 
associated with BPH origin, highlighting the action of Dihydrotestosterone (DHT), a precursor of the hormone testosterone $(T)$. $T$ comes into prostatic epithelial cells where it is converted to DHT by the enzyme 5a-reductase. DHT binds to nuclear androgen receptor $(A R)$ triggering the expression of specific genes in the synthesis of proteins that promote epithelial cell proliferation. Furthermore, DHT stimulates prostatic stroma produce and secrete growth factors that induce cell proliferation ${ }^{5,6}$.

Regression of BPH after decreasing of androgens serum levels and experimental observation that rats treated with $T$ develop adenocarcinoma of the prostate, had showed an association between prostate cancer and these hormones. Androgens do not operate in prostatic genes and only accelerate the growth of pre-existing neoplasms ${ }^{3}$. Furthermore, studies have shown a significant decrease in prostatic proliferation discontinuation of administration of these hormones, and that surgical (bilateral orchiectomy) and chemical (using antiandrogens) castration promotes intense physiological and morphological prostatic regression ${ }^{7,8}$.

Found in foods such as Brazil nuts, cereals, grains and vegetables, and in several enzymes molecules such as glutathione peroxidase and thioredoxin reductase, selenium is a micronutrient that has proven antioxidant action ${ }^{9-11}$. Historically, this has been considered a toxic and carcinogenic element. Its use as anticancer began after 1982, when results of a study showed that selenium had chemo-preventive action in mammary carcinogenesis. Since then, selenium was widely studied as anticarcinogenic, and this effect has been shown in several experimental models ${ }^{12,13}$.

Several studies relating selenium supplementation with immune response, using tumors as a model, have shown that this nutrient in many cases can reduce or inhibit tumor growth, both in humans an rodent models ${ }^{14,15}$. Decreased in incidence of cancer by selenium intake has been shown in epidemiological studies in humans and other animals with selenium supplementation showed a reduction in tumor incidence or tumor size. However, mechanism responsible for this phenomenon is not yet clear, but it is believed that action of selenium in inhibiting tumor growth may comprise the following processes: Antioxidant action on selenoproteins, anti-inflammatory effect associated with immune system, and also changes in gene expression that might block cell cycle progression or induce apoptosis in both tumor and stromal cell precursors ${ }^{13}, 16$ 18. 
This work aimed to verify selenium effectiveness in maintenance of prostate tissue architecture.

\section{METHOD}

Experimental study using 20 adult male Wistar rats, 90 days old were used. All animals used in this project were purchased and kept in a vivarium of the Veterinary Hospital of the University Center of Rio Preto - UNIRP in opaque plastic cages with stainless steel lid with five animals each. During the trial, the environmental conditions were controlled: Temperature $\left(22 \pm 2^{\circ} \mathrm{C}\right)$, relative humidity $(55 \pm 10 \%)$ and period $12 / 12$ light/dark hours. All animals received water and feed ad Nuvilab-CR1 (Nuvital, PR) ad libitum.

Animals were randomly divided into four groups: two control groups (CG1 and CG2) and two experimental groups (TG and TSG). TG group with 5 adult animals received $0.25 \mathrm{~mL}$ for 21 days of testosterone cypionate subcutaneously at a concentration of $25 \mathrm{mg} / \mathrm{mL}$, at intervals of 48 hours ${ }^{19}$. TSG group with 05 adult animals, received testosterone cypionate, subcutaneously, similarity TG group, and weekly doses of selenium (1 mg/ $\mathrm{kg}$ ) by gavage. Control groups were formed by 5 adult intact animals (CG1), and 5 animals that received for 21 days subcutaneous injection of $0.25 \mathrm{~mL}$ of saline and weekly doses of saline by gavage (CG2).

Animals received intramuscular administration of ketamine hydrochloride (Dopalen - $90 \mathrm{mg} / \mathrm{kg}$ ) and Xylazine hydrochloride (Rompun - $10 \mathrm{mg} / \mathrm{kg}$ ) that were made to collect $5 \mathrm{~mL}$ of blood. Then the euthanasia was made by overdose of same anesthetic described. After necropsy, the prostates were fragmented and immersed in fixative for 24 hours. Animal handling and experiments were done according to the ethical guidelines of Rio Preto University Center, following the Guide for Care and Use of Laboratory Animals (Protocol CEUA-UNIRP 593/2013).

Fragments of prostates were fixed in paraformaldehyde and dehydrated in increasing alcohol series $70-100 \%$. The fragments were included in paraffin and then cleared in xylene (two baths of 1 hour and 30 minutes). Then the fragments were embedded in paraffin. The histological sections were stained for Haematoxylin-Eosin $(H E)^{20}$ for general morphological studies of prostatic tissue. 
Analysis was conducted on Axioskop 2-Mot Plus Zeiss microscope (Carl Zeiss, Germany), using AxioVision software for image analysis.

The mean heights of the ventral prostate and seminal vesicle epithelium were determined by 800 random measures at 800x magnification in 10 random fields from the intermediate region for each experimental group, using Image-Pro Plus computer software, version 6.0 (@Media Cybernetics) for Windows ${ }$.

Values are expressed as mean. One-way Anova analysis of variance was performed to determine whether differences existed between all groups $(P<0.05)$, and then the Tukey-Kramer post-test was useded to determine the significance of the differences. A $P$ value of $<0.05$ was considered significant. The statistical tests were performed on Statistica 7.1 computer software (৫ StatSoft Inc.).

\section{RESULTS}

Prostate tissue of CGs animals showed characteristic architecture (Fig. 1a), with secretory epithelium, cubic/columnar epithelial cells and with large amount of secretory vesicles (Fig. 1b). In addition, numerous basal cells have been identified in the epithelium (Fig. 1b). These cells are known to be characteristics of stem cells and are responsible for the renewal of epithelial cell populations. Lumen of prostatic acini presented filled secretion from epithelial cells, demonstrating the high activity of epithelial secretory cells.

The muscular stroma showed a thin layer consisting of smooth muscle cells surrounding the epithelium that forms the secretory acini. Furthermore, in non-muscle stroma was found few extracellular matrix fibers and various blood vessels responsible for irrigation of stroma and epithelium of prostate (Fig. 1c).

Analysis of prostate tissue from TG animals showed an increase in epithelial height and an increase in secretory activity of epithelial cells. Was noted presence of secretion in the lumen of the prostatic acini. Furthermore, the epithelium showed proliferative characteristics, such as stratification and presence of numerous folds into prostatic lumen (Figs. 2Aa-b).

Larger prostatic acini were found in the TG group, and the muscular layer surrounding these acini appeared thinner as compared with the muscular layer surrounding the prostatic acini group CG (Fig. 2a). In prostatic stromal compartment of 
TG animals, there has been a large volume this compartment, which an increase in the apparent volume of the non-muscle stromal compartment.

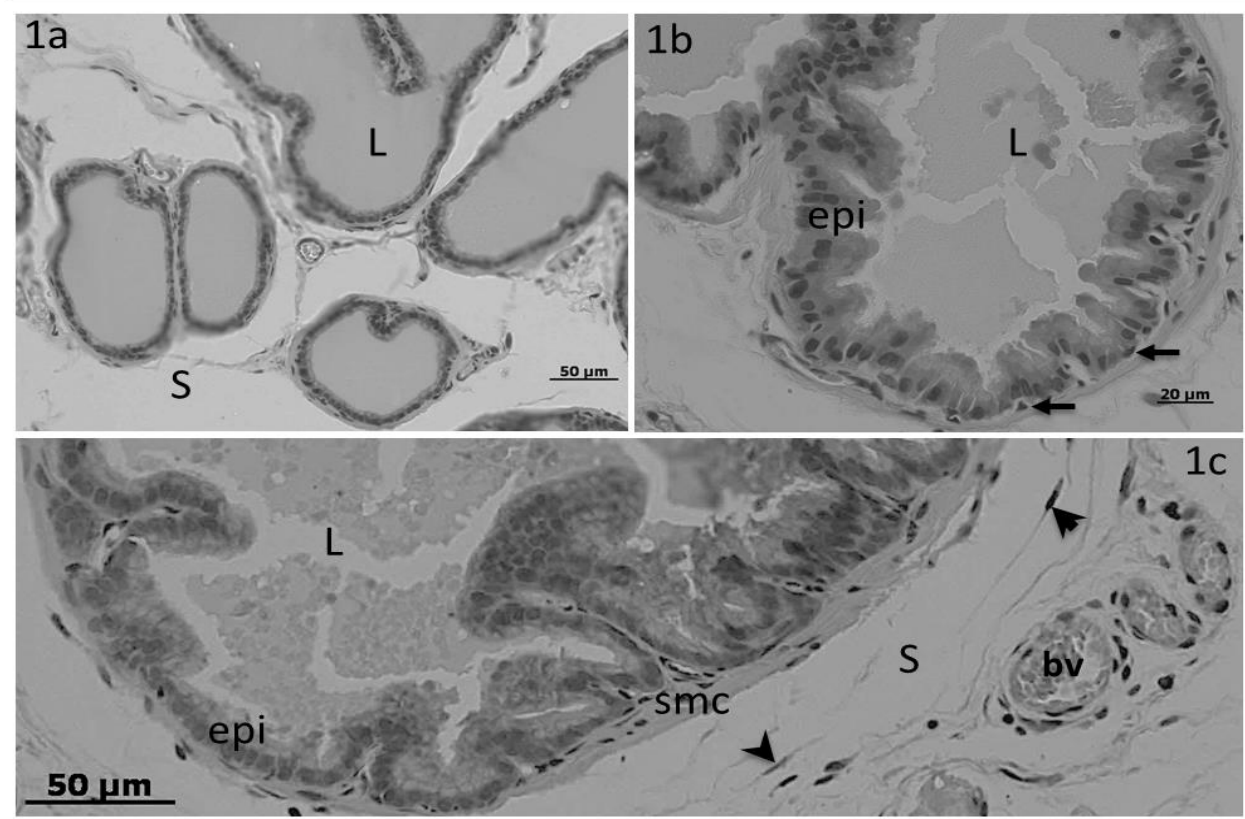

Figure 1 - Histological prostate sections of CG1 and CG2, stained with hematoxylin-eosin. Note secretor epithelium with secretory vesicles $(a, b$, c). In the stroma, note blood vessels and fibroblasts (c) L: lumen; S: stroma; epi: epithelium; smc: smooth $m$ muscle cell; arrow: basal cell; arrowhead: fibroblast; bv: blood vessel.

Even in the stroma, the prostate of animals TG was found a lot of blood supply, with higher frequency of small caliber blood vessels (Figs. $2 c$ and e). Besides excessive proliferation of TG prostate epithelium, some proliferative lesions could be identified as hyperplasia (HYP) and prostatic intraepithelial neoplasia (PIN) (Figs. 2d-f).

Prostatic epithelium of TSG showed high cells with large secretory activity, which shows intense proliferative activity (Figs. 3a-b). The epithelium showed a large amount of folds, in which it may be noted that the cells had proliferative activity points because there is stratification (Fig. 3d).

Foci of PIN and HYP could be identified in the epithelium of the TSG group of animals. Surrounding epithelium of prostatic acini was found a smooth muscle layer, forming muscle stroma (Fig. 3d). In non-muscular stroma, which showed large amount of extracellular matrix fibers, were identified a large amount of blood vessels (Figs. $3 \mathrm{c}$ and e).

Morphometrical data of prostate epithelium height showed statistical difference between all groups $(P<0.05)$ with $6.85 \mu \mathrm{m}$ in $C G, 12.6 \mu \mathrm{m}$ in TG and 13.37 $\mu m$ in TSG prostate epithelium (Table 1). 
Table 1 - Morfometrical data of prostate epithelium.

\begin{tabular}{lll}
\hline Group & Epi Height $(\mu \mathrm{m})$ & Std Err \\
CG & $6.85^{a}$ & 0.07 \\
TG & $12.6^{b}$ & 0.10 \\
TSG & $13.37^{c}$ & 0.08
\end{tabular}

Note: CG: Control Group; TG: Testosterone Group; TSG: Testosterone and Selenium Group. Different indices means significant differences between groups.

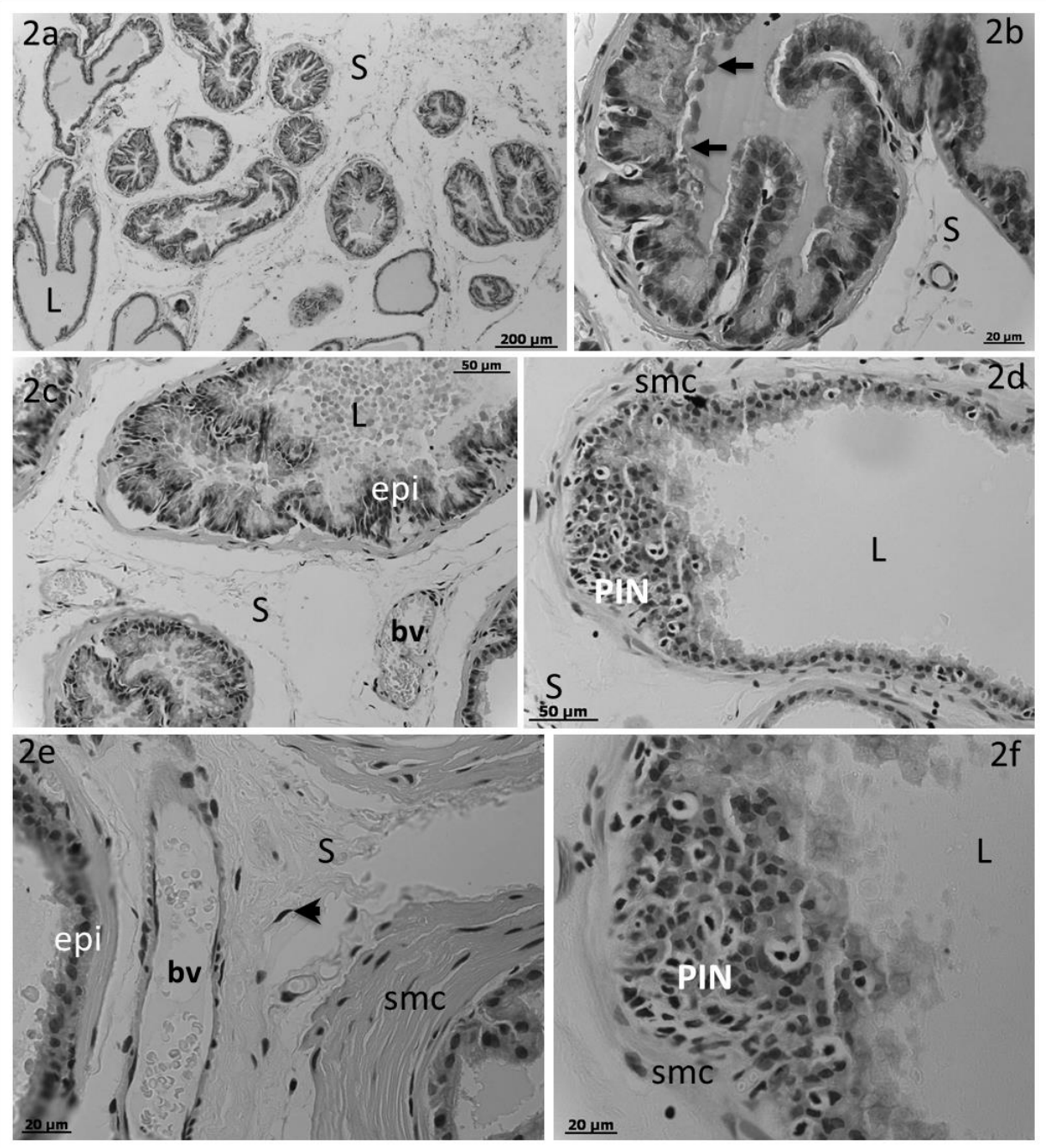

Figure 2 - Histological prostate sections of TG, stained with hematoxylin-eosin. Proliferative epithelium with intense secretory activity $(a, b, c)$, and presence of proliferative lesions, like PIN $(d, f)$. In stromal compartment, note blood vessels (e) L: lumen; S: stroma; epi: epithelium; smc: smooth muscle cell; arrow: secretion; arrowhead: fibroblast; bv: blood vessel; PIN: Prostatic Intraepithelial Neoplasia. 


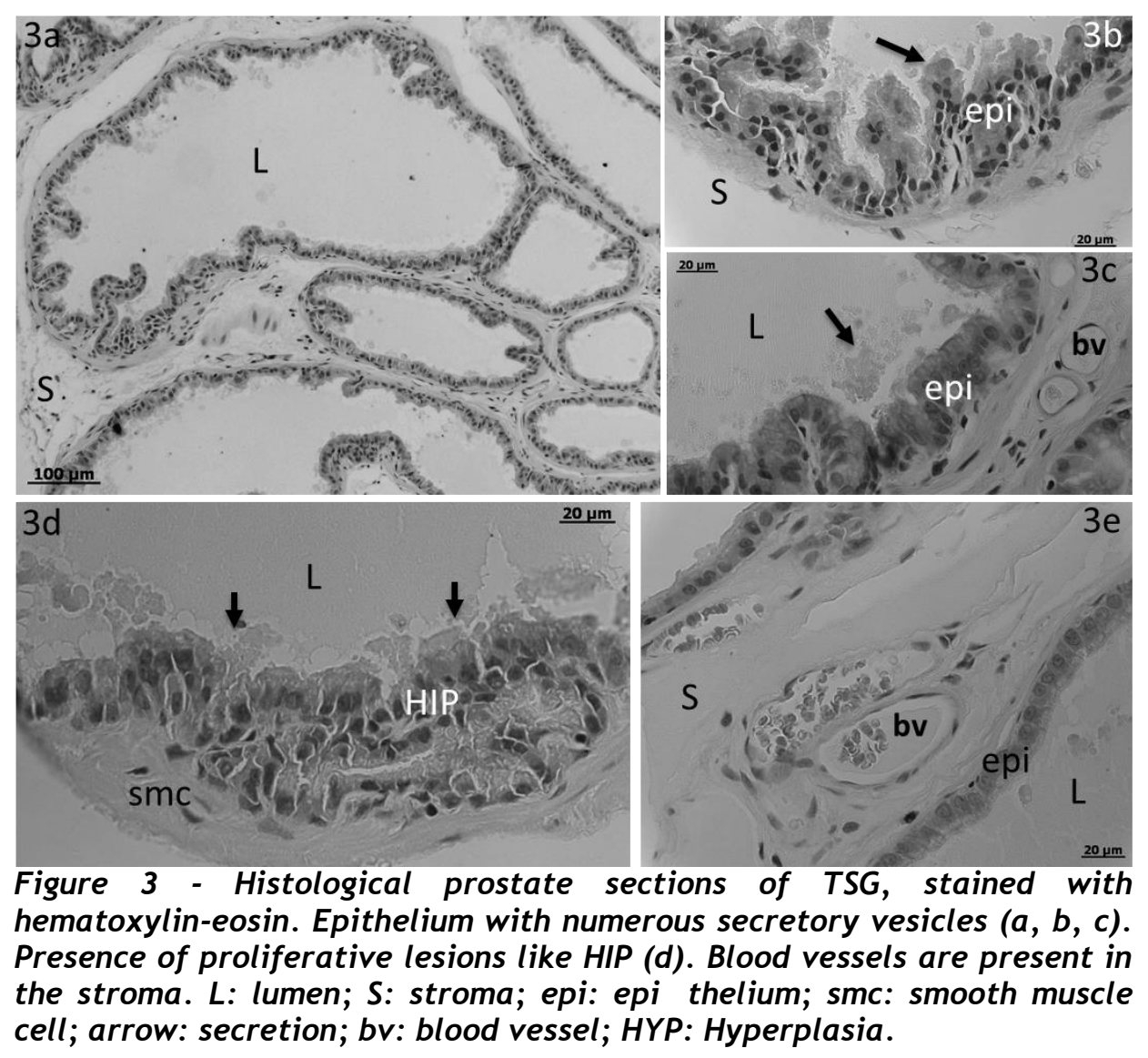

\section{DISCUSSION}

In this study we used selenium, a micronutrient that has been considered to be an anti-oxidant with anti-inflammatory and anti-viral activities ${ }^{21}$, to verify the effectiveness of this compound against proliferative lesions in rat prostate. Selenium has been associated with two aspects: Initially the only concern for this element was its toxicity; nowadays it is recognized that this element can prevent certain types of cancer $^{22}$.

Prostate tissue of CG animals were in accordance with those expected for the prostatic epithelium of rodents ${ }^{23}$ including basal cells that are responsible for the renewal of epithelial cell populations and high of epithelium.

Androgens are essential for prostatic growth and development but they also have a significant function in prostate disease pathogenesis ${ }^{24}$. Both normal and pathological growth of the prostate is dependent on dihydrotestosterone (DHT). In this way, all features found in prostatic compartments of TG prostate demonstrated the action of $T$ in maintaining proliferative and secretory activity of this gland and cell 
proliferation in prostatic epithelium, that can be responsible for the emergence of various proliferative lesions ${ }^{7,25}$.

In TSG, epithelial height and morphological prostate characteristic were very similar than the TG, that denotes the role of $T$ in modulation of epithelial architecture and the ineffectiveness of Se in protect epithelial gland against $T$ stimulant effects. Proliferative activity was evident, as seen in TG, due epithelium stratification and presence of innumerous blood vessels in stroma. This proliferation can be responsible of emerging proliferative lesions foci ${ }^{26}$, as HYP, a disorder that has been identified in man and is associated with prostate cancer ${ }^{27,28}$.

Is not known yet the mechanism by which Selenium act as an anti-carcinogenic element, but several speculative hypotheses have been proposed. It is well established that the most effective dose of Selenium for cancer protection is at elevated levels, often called supra-nutritional or pharmacological levels ${ }^{22}$. This may explain why the dose used in this study $(1 \mathrm{mg} / \mathrm{Kg})$ did not cause the protect effect against morphological modifications promoted by $T$ in prostate gland tissue. The suggested mechanisms of Se action include effects upon apoptosis, DNA repair, activating immune system pathways, working as an anti-angiogenic agent and its specific inhibition of tumor cell growth by certain Selenium metabolites ${ }^{22}$.

\section{CONCLUSION}

As secretory activity and epithelial characteristics, as well as the presence of proliferative lesions were also described in both TG and TSG groups, it can be concluded that administration of selenium in concentration of $1 \mathrm{mg} / \mathrm{Kg}$ seems to have no effectiveness in modulating morphology of prostatic tissue of adult rats when under influence of exogenous testosterone, which is known to promote morphological and physiological modification in this gland.

However, through these studies, it was not possible to determine the real reason for this low dose of selenium intake did not promote some protection against testosterone stimulation. Further research is needed in order to compare different concentration of Selenium and understand the mechanisms which this mineral act in prostate tissue. 


\section{REFERENCES}

1. Price D. Comprative aspects of development and structure in the prostate. Nat Can Inst Monogr. 1963; 12:1-27.

2. Brandes $D$. The fine structure and histochemistry of prostatic glands in relation to sex hormones. Int Rev Cytol. 1966; 20:207-76.

3. Srougi M, Ribeiro LA, Piovesan AC, Colombo JR, Nesrallah A. Prostate Diseases. Rev Med. 2008; 87(3):166-77.

4. Filho GB, Pereira FEL, Pitella JEH, Bambirra EA, Barbosa AJA. Bogliolo: Patologia Geral. Rio de Janeiro (RJ): Guanabara Koogan; 1993.

5. Roosen A, Gratzke C, Herrlemann A, Magistro G, Strittmatter F, Weinhold P, et al. Etiology and pathophysiology of benign prostate hyperplasia. Urologe A. 2013; 52(2):186-92.

6. Banerjee PP, Banerjee S, Brown TR, Zirkin BR. Androgen action in prostate function and disease. Am J Clin Exp Urol. 2018; 6(2):62-77.

7. Oliveira SM, Vilamaior PSL, Corradi SL, Goes RM, Taboga SR. Cellular and extracellular behavior in the gerbil (Meriones unguiculatus) ventral prostate following different types of castration and the consequences of testosterone replacement. Cell biol int. 2007; 31(3):235-45.

8. Corradi LS, Goes RM, Carvalho HF, Taboga SR. Inhibition of 5-alpha-reductase activity induces stromal remodeling and smooth muscle dedifferentiation in adult gerbil ventral prostate. Differentiation. 2004; 72(5):198-208.

9. Liu M, Yao W, Zhu Y, Liu H, Zhang J, Jia L. Characterization, antioxidant and antiinflammation of mycelia selenium polysaccharides from Hypsizygus marmoreus SK-03. Carbohydr Polym. 2018; 201:566-74.

10. Kryscio RJ, Abner EL, Caban-Holt A, Lovell M, Goodman P, Darke AK, et al. Association of Antioxidant Supplement Use and Dementia in the Prevention of Alzheimer's Disease by Vitamin E and Selenium Trial. JAMA Neurol. 2017; 74(5):56773.

11. Ferguson LR, Philpott $M$, Karunasinghe N. Dietary cancer and prevention using antimutagens. Toxicology. 2000; 197(1-3):147-59.

12. Thompson HJ. Selenium as an anticarcinogen. J. Agric. Food Chem. 1984; 32(3):4225. 
13. Petrie HT, Klassen LW, Klassen PS, O'Dell JR, Kay HD. Selenium and the immune response: 2. Enhancement of murine cytotoxic T-lymphocyte and natural killer cell cytotoxic in vivo. J Leukoc Biol. 1989; 45(3):215-20.

14. Peters KM, Carlson BA, Gladyshev VN, Tsuji PA. Selenoproteins in colon cancer. Free $\begin{array}{lllll}\text { Radic Biol } & \text { Med. }\end{array}$ https://doi.org/10.1016/j.freeradbiomed.2018.05.075.

15. Reid ME, Duffield-Lillico AJ, Garland L, Turnbull BW, Clark LC, Marshall JR. Selenium supplementation and cancer incidence: An update of the nutritional prevention of cancer trial. Cancer epidemiol biomark prev. 2002; 11(11):1285-91.

16. Whanger PD. Selenium interactions with carcinogens. Fundam Appl Toxicol. 1983; $3(5): 424-30$.

17. Avery JC, Hoffmann PR. Selenium, Selenoproteins, and Immunity. Nutrients. 2018; 10(9):E1203.

18. Vance TM, Su J, Fontham ET, Koo SI, Chun OK. Dietary antioxidants and prostate cancer: a review. Nutr Cancer. 2013; 65(6):793-801.

19. Pollard M, Luckert PH. Autocthonous prostate adenocarcinomas in Lobund-Wistar rats: a model system. Prostate. 1987; 11:219-27.

20. Tolosa EMC, Rodrigues CJ, Behmer AO, Freitas Neto A. Manual de práticas para histologia normal e patológica. $1^{\text {a }}$ ed. São Paulo: Manole; 2003.

21. Papp LV, Lu J, Holmgren A, Khanna KK. From selenium to selenoproteins: Synthesis, identity, and their role in human health. Antioxid Redox Signal. 2007; 9:775-806.

22. Hurst R, Hooper L, Norat T, Lau R, Aune D, Greenwood DC, et al. Selenium and prostate cancer: systematic review and meta-analysis. Am J Clin Nutr. 2012; 96(1):111-22.

23. Hayashi N, Sugimura Y, Kawamura J, Donjacour AA, Cunha GR. Morphological and functional heterogeneity in the rat prostatic gland. Biol Reprod. 1991; 45(2):308-21.

24. Tindall DJ, Rittmaster RS. The rationale for inhibition 5alpha-reductase isoenzymes in the prevention and treatment of prostate cancer. J Urol. 2008; 179(4):1235-42.

25. Carson C, Rittmaster RS. The role of dihydrotestosterone in benign prostatic hyperplasia. Urology. 2003; 61(4 Suppl 1):2-7.

26. Galbraith SM, Duchesne GM. Androgens and prostate cancer: Biology, pathology and hormonal therapy. Eur j cancer. 2007; 33(4):545-54. 
Oliveira SM, Silva LS, Ledesma RHC, Silva RG. Histological analysis of rat prostate under exogenous...

27. Ørsted DD, Bojesen SE. The link between benign prostatic hyperplasia and prostate cancer. Nat Rev Urol. 2013; 10(1):49-54.

28. Marcelli M, Cunningham GR. Hormonal signaling in prostatic hyperplasia and neoplasia. J Clin Endocrinol Metab. 1999; 84(10):3463-8.

Conflito de interesses: Os autores declaram não haver conflito de interesses.

Participação dos autores:

- Concepção: Oliveira SM.

- Desenvolvimento: Oliveira SM, Silva LS, Ledesma RHC, Silva RG.

- Redação e revisão: Oliveira SM.

Como citar este artigo: Oliveira SM, Silva LS, Ledesma RHC, Silva RG. Histological analysis of rat prostate under exogenous testosterone and low dose of oral selenium administration. Journal Health NPEPS. 2018 juldez; 3(2):380-391.

Submissão: $28 / 08 / 2018$

Aceito: $01 / 12 / 2018$

Publicado: 30/12/2018 